https://helda.helsinki.fi

\title{
Capitalism Russian-style
}

\section{Piirainen, Timo}

Venäjän ja Itä-Euroopan tutkimuksen seura 1994

Idäntutkimus. 1 (1994) : 1 , s. 72-73.

http://hdl.handle.net/10138/9850

Downloaded from Helda, University of Helsinki institutional repository.

This is an electronic reprint of the original article.

This reprint may differ from the original in pagination and typographic detail.

Please cite the original version. 
teita, joiden täytyy jäädä suurelle enemmistölle vieraiksi. Tilanne muistuttaa enemmän tai vähemmän Pietari Suuren aikoja, sekä muutoksen rajuuden että sen yhteiskunnallisen epätasaisuuden osalta. Ehkäpä syntymässä - tai uutta puhtia saamassa - on taaskin spengleriläinen "pseudomorfoosi": näennäisesti länsimainen kulttuuri, joka ytimeltään on kuitenkin syvästi erilainen. Mikăli yhdytään Brzezinskin arvioon amerikkalaisuudesta, ei onneksi ole pelkoa siită, ettă venälăinen muoto olisi esikuvaansa merkittävästi huonompi.

\section{Timo Vihavainen}

\section{Capitalism Russian-Style}

Daniel Yergin \& Thane Gustafson: Russia 2010 and What It Means for the World. Random House, New York 1993. 300 s.

$\mathrm{K}$ ahdenkymmenen vuoden päästä me olemme normaali maa, viidenkymmenen vuoden päästä me olemme hyvin vauras maa, ja sadan vuoden päästä muu Eurooppa tulee liittymään meihin", esittää anonyyminä pysyttelevä venäläinen taloustieteilijä Daniel Yerginin ja Thane Gustafsonin futurologisessa teoksessa Russia 2010 and What it Means for the World.

Yergin, kansaivälisten suhteiden tutkija ja taannoinen Pulitzer-palkinnon voittaja ja Gustafson, Venäjän talouden ja politiikan professori Georgetownin yliopistosta, eivät kuitenkaan ulota viime vuoden lopulla ilmestyneessä kirjassaan rakentamiaan Venäjän tulevaisuutta kuvaavia skenaarioita sadan tai edes viidenkymmenen vuoden päähän. Tarkastelun aikaväli on keskipitkä: kuten jo kirjan nimestä käy ilmi, skenaariot ulottuvat ainoastaan vuoteen 2010 - vuosilukuun, jolloin perestroikan alkamisesta on tullut kuluneeksi 25 vuotta.

Vuoteen 2010 mennessä Venäjä on siis niin kirjoittajien kuin heidän siteeraamansa tuntemattoman ekonomistin mielestä - siirtynyt "normaalien" maiden joukkoon. Tälle normaalitilalle Yergin ja Gustafson antavat nimen $\mathrm{Ca}$ pitalism Russian-Style: Venäjä on tuolloin mukautunut osaksi kapitalistisen maailman työnjakoa ja omaksunut kehittyneille markkinatalousmaille ominaiset yhteiskuntaelämän pelisäännöt.

Yergin ja Gustafson rakentavat kolme mahdollista peruskehitystietä kohti tuota yhteistä päätepistettä - kapitalismin venäläistä varianttia. Ensimmäisen skenaarion kirjoittajat ovat nimenneet "Venäläiseksi karhuksi" tai "Kaksipäiseksi kotkaksi". Nimitykset viittaavat autoritaariseen ja antidemokraattiseen kehitykseen transitiovaiheen aikana; huomattava määrä yhteiskunnallista valtaa siirtyisi toisaalta neuvostoaikaisen teollisuusjohdon sekä toisaalta puolustusvoimien ja muiden turvallisuuselinten - kotkan kahden pään - muodostamalle akselille.

Toinen mahdollinen kehitystie on nimeltään "Pitkät jäähyväiset". Hyvästijättö autoritaariselle keskusvallalle jatkuisi tässä skenaariossa keskusvallan otteen edelleen heikkenemisenä Venäjän federaation sisällä ja erilaisina sinnikkäästi jatkuvina desentralisoitumis- ja fragmentoitumistendensseinä. Kapitalismin normaalitilaa edeltäisi siis pitkähkö hajaannuksen kausi, smutnoe vremja. Hajaannus voisi myös saada aikaan autoritaarisen ja totalitaristisen vastareaktion, synnyttää pyrkimyksiä kohti vahvan keskusvallan palauttamista.

Kolmantena vaihtoehtoisena kehitystienä on ekonomitsheskoe tshudo, venäläinen talousihme Saksan tai Japanin tapaan. Edellytykset talousihmeeseen ovat - lähtötilanteen masentavuudesta huolimatta - olemassa: koulutettu ja ammattitaitoinen väestö, runsaat luonnonvarat, kilpailijamaita suhteellisesti alhaisempi palkkataso sekä valtava potentiaalinen kysyntä erilaisille kulutus- ja investointitavaroille.

Yerginin ja Gustafsonin esittämät kehitysskenaariot eivät vaikuta mitenkään erityisen omaperäisiltä ja oivaltavilta. Teoksen ansiot ovat tulevaisuudentutkimuksen asemesta pikemminkin Venäjän lähtökohtien ja nykytilan monipuolisessa kuvaamisessa. Vuosi 2010 jää kaikessa kapitalistisessa itsestäänselvyydessään varsin värittömäksi; Venäjän lähtötilannetta ja nykyisen transitiovaiheen ongelmia kirjoittajat sen sijaan pystyvät esittelemään ja analysoimaan kiistattoman asiantuntevasti ja laajaalaisesti. Parhaimmillaan Yergin ja Gustafson ovat nimenomaan piirtäessään journalistisin pikavedoin, anekdootteja ja tarinoita sinne tänne sirotellen, kuvaa rakenteellisista ongelmista tämän päivän Venäjällä; aihepiiristä kelpo bestsellertyyliin kirjoitettua tiivistelmää etsivälle Russia 2010 -teosta voi varauksetta suositella.

Autoritaarisen keskusvallan ja toisaalta desentralisoitumis- ja regionalismipyrkimysten välistä jännitettä voidaan ilman muuta pitää yhtenä maantieteellisesti jättiläiskokoisen val- 
takunnan historiaa - ja tulevaisuutta - keskeisimmin muovaavista tekijöistä. Yergin ja Gustafson ovatkin valinneet autoritaarinen keskusvalta - desentralisoituminen -akselin Venäjän kehitysvaihtoehtoja kuvaavia skenaarioita määrittäväksi ulottuvuudeksi. Kirjoittajat rakentavat skenaarionsa varioimalla tätä keskusvalta - desentralisaatio -muuttujaa: vahva keskusvalta tuottaa valtiopaternalistisen kehitystien, heikko keskusvalta puolestaan aiheuttaa harharetken anarkiaan ja hajaannukseen ennen tavoitetilan saavuttamista. Talousihme syntyy vastaavasti tasapainosta keskittymis- ja hajaantumispyrkimysten välillä.

Asiat yksinkertaistuvat kuitenkin luvattoman paljon, jos kysymys keskusvallan asemasta nostetaan ainoaksi tulevaisuutta muovaavaksi tekijăksi. Vahva ja legitiimi keskusvalta ei sitäpaitsi välttämättă ole autoritaarista valtaa, kuten Yergin ja Gustafson näyttävät otaksuvan; autoritaarinen valtiovalta ja fragmentoitumistendenssit voivat pikemminkin olla samanaikaisesti esiintyviä ilmiöitä kuin vastakkaisia vaihtoehtoja.

Väestöryhmien ja yhteiskuntaluokkien väliset jännitteet voivat Venäjän tulevaisuutta hahmoteltaessa olla keskusvaltaproblematiikkaa merkittävämpiä tekijöitä. Vanha neuvostoegalitarismi on Venäjän basaarikapitalismin oloissa nopeasti vaihtunut räikeäksi eriarvoisuudeksi. Yergin ja Gustafson eivät kuitenkaan liiemmin pohdi esimerkiksi jyrkkien tuloerojen ja sosiaalisen epäoikeudenmukaisuuden vaikutusta Venäjän tulevaisuudenkuvia muotoillessaan.

Modernisoitumis- ja konvergenssiteoriat ovat parin vuosikymmenen tauon jälkeen tulleet taas muotiin reaalisosialismin romahduksen ja maailmanjärjestelmien välisen kilpailun päättymisen myötä. Yerginin ja Gustafsonin teos edustaa tämän uuden konvergenssiteorian mainstreamia. Kaikkien kehitysteiden päätepiste on sama: Capitalism Russian-Style. Futurologian palvelukseen valjastettuna konvergenssiajattelu tuottaa varsin triviaaleja ja/tai ideologisesti ladattuja tulevaisuudenkuvia. Vauraudella, sivistyksellä ja yhteiskunnallisella vakaudella ihmiskuntaa kaikkialla siunaavan maailmankapitalismin syntymiseen vuoteen 2010 mennessä on sittenkin vaikea uskoa. Konvergenssiajattelua hyödyllisempää olisi yrittää tunnistaa ja analysoida niitä uusia ristiriitoja, joita maailma yhä kiihtyvällä vauhdilla tuottaa ihmeteltäväksemme.
Russia 2010 -kirjan materiaali on nähtävästi ollut koossa kesällä 1993. Sen jälkeen on Venäjällä tapahtunut paljon. Hajoamistendenssit ovat tulleet päätepisteeseensä ja keskusvallan ja alueiden suhteet ovat normalisoitumassa. Demokraattisissa vaaleissa valittu parlamentti on syventynyt - vastoin kaikkia ennakko-odotuksia - perehtymään demokratian pelisääntöihin. Inflaatio on talttunut vajaan kymmenen prosentin kuukausivauhtiin.

Yerginin ja Gustafsonin mukaan nyt tulisi seurata Talousihme ja sitten myöhemmin Capitalism Russian-Style.

Tapahtuuko todella näin?

Tuskin. Tapahtuu jotakin aivan muuta.

Timo Piirainen

\section{Presidentin päiväkirja}

Boris Jeltsin: Presidentin päiväkirja. Otava, Helsinki 1994.416 s. + kuvat.

Venäjän presidentti Boris Jeltsin on viimeiset vuodet käynyt poliittista kamppailua useammalla eri rintamalla. Yhtäältä hän on pyrkinyt ajamaan uudistuksiaan läpi erilaisin lainsäädännöllisin keinoin turvautuen kuitenkin aina välillä myös radikaalimpiin toimenpiteisiin, viimeksi lokakuussa 1993 asevoimien tukeen. Hänen päiväkirjansa (tai pikemminkin muistiinpanonsa sananmukaisesti suomennettuna) kattaakin yhden kaikkein merkittävimmistä vaiheista Venäjän 1900-luvun historiassa. Kyseessä on vaihe, jonka aikana on jouduttu tai pyritty tekemään ne ratkaisevat toimenpiteet, jotka mahdollistavat maan siirtämisen länsimaiseen demokratiaan ja markkinatalouteen. Päiväkirjat alkavat vuoden 1991 alkupuolelta ja päättyvät lokakuuhun 1993, jolloin Jeltsin uskoi jo ratkaisseensa lopullisesti valtataistelunsa parlamenttia kontrolloineiden vanhoillisten voimien kanssa.

Presidentin päiväkirjat on avoimesti poliittinen teos - poliittinen teko, jonka tarkoituksena ei ole ainoastaan paljastaa, kuka teki mitä kenelle $(k$ to $k o g o)$ viimeisten kahden ja puolen vuoden aikana, vaan myös ja ennen muuta vaikuttamaan Venäjän tulevaan poliittiseen kehitykseen. Aikaperspektiivi ulottuu ainakin vuoteen 1996, jolloin Venäjällä on määrä järjestää seuraavat presidentinvaalit. Vaikka Jeltsin on useaan otteeseen ilmoittanut, että hän ei ole 